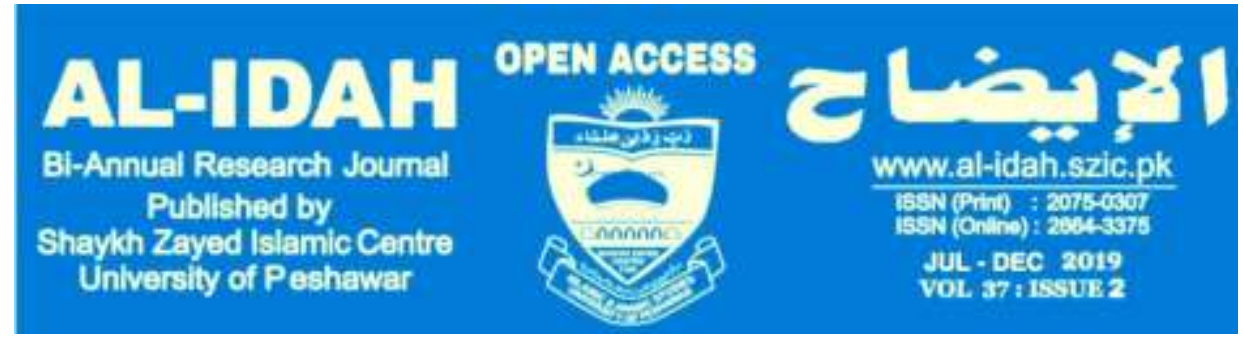

\title{
Honour Killing in the Light of Islamic Law and Prevailed Customs in Pakistan
}

\author{
Dr. Qaisar Bilal
}

Lecturer, Kohat University of Science \& Technology

\author{
Dr. Hussain Muhammad \\ Assistant Professor, University of Science \& Technology Bannu
}

\begin{abstract}
:
Islamic law consists hundreds of rulings that encourage the trends and cultural norms of a society in one form o other. Similarly, it also strongly confines suc. mannerisms and social traits which are considered goo and which affect the order of society and may lead $t$ exploitation of rights of any gender. Sharia's teaching consider it illegitimate and unlawful.

"Honour Killing" is one of the prevalent customs acros the nation with different local names. It is an extremely brutal act that violating not only sharia's express laws but also reflects mercilessness and inhumanity. Regrettably, in Pakistan this awful deed is measured as an act of appreciation and is not only regarded likeable and acceptable but is also considered a matter of pride and honour redemption.

This study mainly focuses on highlighting the sharia's rulings about the nature of Honour killings and reveals to what extent it deviates from the main stream Islamic law. The administrative loopholes of the conventional judiciary system of Government of Pakistan have also been touched in in this article.

Keywords: Honour Killing, Iftyāt, interruption in Government Affairs Kārūkārī, illegitimate relation of couple.
\end{abstract}

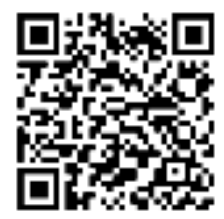

Scan for Download

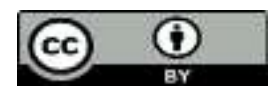




\section{Introduction:}

Honour killing means when a man and a woman enter into the contract of marriage without the approval of their elders or society (even though the nature of the relationship is legal and acceptable in the light of Islamic teachings) both of them are given death punishment. To kill a man or a woman on the basis of such relation is called Kârūkâri. Karo is used for the man while Kari is used for the woman. This dreadful act is considered as an act of valour and is not only acceptable but approved and is considered a thing to be proud of. Though this problem is present all over Pakistan but the province of Sindh is replete with such incidents. Tribal and racial domination, social prejudices and feudalism are still considered a source of social distinction and pride. Kārūkāri is not only unIslamic but its commitment pushes the society towards quagmire of mutual hostility and family rivalry over the years making the retreat impossible. Not only few fledgling lives are its prey but the whole society gets blemished and the lives of many families become the fuel of hellfire. This evil casts a terrible and disturbing picture of Pakistani society all over the world. Honour refers as "involvement of another person in a particular thing resulting in the alteration or anger in the heart of owner is called honour". ${ }^{1}$

Honour is the variation of inner state and condition of man arising from seeing any unpleasant thing in the society. As for instance, if a man sees his wife sitting in the lap of another man in an objectionable state, he wants to kill both of them on the basis of this shameful act. However, a perfect Muslim would seek Islamic advice and commandments in the said matter. While In Shariah (Islamic Teachings), "honour is the anger resultant from seeing another person's breaching of Allah's commandments and prescribed set of laws."

\section{Literature Review:}

The meaning of honour is taken differently in different societies. For instance, treating women as a working tool in the Arab society was considered an act of shame and it was an indication of men's lack of courage, self-consciousness and inferiority in terms of honour ${ }^{2}$. According to Patel $2008^{3}$, it is not necessary that honour will only be confined to men; rather it may be seen in women folk too according to the requirement of human nature. Imām Bukhārī has regulated a chapter with the title "Bāb-e-Ghairatun'nisāe Wa Wajadahun". 4

Moreover Honour is also used in the meaning of anger and jealousy as Ayesha (May Allah be pleased with her) said that Prophet Muhammad used to mention Hadrat Khadija (May Allah be pleased with her) so many times that it used to result in her irritation ${ }^{5}$. It is narrated by Umm-e-Salma when the Prophet sent the message of marriage to her, she said, "O Messenger of Allah! "إي امرأة غيرى (I am a jealous woman)" The same interpretation of honour as anger or emotional reactions has been quoted by Green and Sibini $2006 .^{7}$

There are many recent studies which state that honor killing is supported by custom and it is prevalent in North Africa and Middle East including Turkey and Pakistan $^{8}$. The honor murder is also known as Kāro-Kārī. Kāro (Black male) and Kārī (Black female). Kāro-Kārī is the murder of both the guilty persons which 
lead to the dishonor of the family. Survey reports state that about one thousand females were murdered previous year [3]. 472 cases of honor murder were registered in 2009; amongst them 91 from Punjab, 220 from Sindh, 32 from KPK, 127 from Baluchistan and 2 from Islamabad. Many studies state that honor killing is an act of violence which gives female the cause of to live under the banner of honor. ${ }^{9}$

The expression 'honor' crime is a broad term and it consists of various demonstrations of violence. This demonstration depicts 'honor' killing, sexual assault, confinement, or forced marriages ${ }^{10}$.. Amongst all South Asian countries, Pakistan is mostly highlighted when it comes to honor killing because there is the existence of contradiction of Islamic laws and implementation at the state level ${ }^{11}$.

Violence against women varies in different states. The comprehensive distinction in proportion of violence against women in different countries intimate that hypothetically adaptable cultural aspects play a pivotal role in defining both actual rates of violence and attitude towards its acceptability ${ }^{12}$. According to UNFPA report, there are almost 5000 women killed every year in Pakistan in the name of honor ${ }^{13}$. Different provinces within Pakistan exhibit different culture and tradition with the dominant male perspective in the society, thus being a patriarchal society. It is evident by Patel and Gadit that Pakistani society is still following the traditional decision-making system known as Jirga despite proper legal authorities, laws and acts. According to Wasti and Niaz the Pakistani society adopted the practice of honor killing since pre- partition from the Indian subcontinent. In addition, Koteweg \& Yurdakul explain in their article that Pakistani society has some anti- Islamic customs and values since long. It will be discussed below in the framework analysis, with the support of evidence found in the research of Douki et al. that such practices include women being buried alive due to gender discrimination, if they are involved in sexual activities. ${ }^{14}$ Customarily honour is to make a person ashamed of doing a particular work or saying something to vary his inner feelings inciting him to be ready for a certain work.

\section{Discussion:}

Islam has given every type of freedom to women- folk but with some prescribed limits. The evil acts of murdering women in the name of honour can never be justified in Shari'ah as Islam has given equal rights to both men and women.

Islam has given equal educational rights to both men and women. Prophet Muhammad assigned the duty of Hafsa (May Allah be pleased with her) to teach Shafā Bint Abdullah (May Allah be pleased with her). ${ }^{15}$ Similarly a companion, named Fatima Bint-e-Qais (May Allah be pleased with her) who was among the firstly migrated women, used to teach Hadithto female companions who gathered in her home ${ }^{16}$.

Islam has also permitted women to present their demands to higher authorities in case it is not presented satisfactorily on their behalf by men owing to some reasons. They can do so through making their own representatives. Once a Sahābia, named Umm-e-Salma (May Allah be pleased with her) who became the representative of women folk, presented legitimate demands of women to the 
prophet and delivered an eloquent speech. On hearing it, prophet asked his companions, "Did you hear women asking questions about their religion in such a decent way? They said, "O messenger of Allah! Really we did not hear anyone before asking such questions". Then the Prophet instructed that woman and told her to convey the same message to her colleagues. ${ }^{17}$

A woman is even permitted to drive if she is in a situation where she is not accompanied by men and she knows well how to drive. One such example is that of Umm-e-Salma (May Allah be pleased with her) who prepared her own camel and departed for Madīna as she didn't have any men because her husband had already been migrated. Reaching Tanim name of a place), a person met her who caught her camel's rope and took her. ${ }^{18}$

A Sahāabia, named Zainab (May Allah be pleased with her) was a hard-working woman. She used to make different things and sell those for supporting her husband and children. Before accepting Islam, she enquired from the prophet about her profession and earning and he allowed her. Afterwards she embraced Islam. ${ }^{19}$ Islam did not stop at all any woman to serve in public office. She was given full representation if capable of doing work in the public office. For example Shafa Bint Abdullah (May Allah be please with him) was a very talented, intelligent and learned Sahäbia. Sometimes the Holy Prophet used to take rest at her place due to which Umar (May Allah be pleased with her) used to take great care of her and take her opinion of great importance. She was appointed as an in charge of market by Umar (May Allah be please with him $)^{20}$.

Samra bint Nāhik (May Allah be pleased with her) was an elderly woman. She used to patrol in the streets with a whip in her hand. She belonged to the field of Amar Bil Ma'rūf Wa Nahī an al-Munkar (Preaching mankind to do good and refrain from $\sin ){ }^{21}$

Islam has given legitimate rights to women of entertainment and permitted them to express their happiness freely. For example, there was a marriage ceremony in a house in Madina to whom Ayesha (May Allah be pleased with her) sent some gifts. Prophet Muhammad asked if she had sent any singer as well because Ansar (Inhabitants of Madina) liked songs. Ayesha (May Allah be pleased with her) answered in the negative to which Prophet Muhammad directed her to search and send a woman, named Zainab (May Allah be pleased with her) who used to sing songs in Madina. ${ }^{22}$

The above mentioned rights depicts the facts that sharia's standards about the women rights are very vibrant and open and there is not any restriction which deprives them from their basic rights and needs. The religion Islam gives them equal chance to live in a free environment.

\section{Prevailed Customs and Woman Status in Islamic Jurisprudence Context:}

Prevailed customs in some specific areas across the nations are entirely different and oppose the Shari'ah rulings in one way or the other. Women manage the household responsibilities Usually a woman is murdered brutally against false charges of adultery if she exercises her right to choose her mate. Generally in such a situation, parents do not accede to such a proposal and thus court marriages 
take place. Clearly Islamic Shariah gives this right to a Muslim woman and the resultant brutal killings in the name of honour are baseless and purely egoistic.

According to the majority of jurists, a woman cannot hold her Nikah (marriage) by herself; rather her parents/guardians are authorized to hold her marriage. While Imām Abū Hanīfa says that a man and a woman can be bonded in a valid Nikāh if both of them agree in the presence of two witnesses. His interpretation holds both man and woman autonomous and authorized to decide about their life partners.

Besides most of the jurists submit the narration of Abu Musa as an argument, ע', "There is no marriage except with consent of a guardian."

Similarly, it is narrated by Ayesha (May Allah be pleased with her) that women holding marriages without guardian's consent is thrice void.

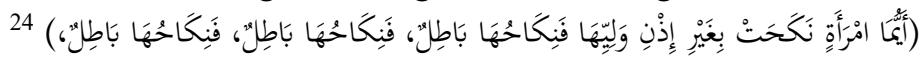

Whereas religious scholars are of the view that Allah has given women the autonomy of their lives which is clear from his commandment in Surah alBaqarah verse: 232, that those divorced women who reached to their terms should be allowed to remarry according to their wishes and that their guardians should not go against their decisions. ${ }^{25}$ The said verse was revealed about IbnYasar who forbade his sister to go back to her ex-husband.

So it indicates that women have due proper right to choose their spouses. Sahih

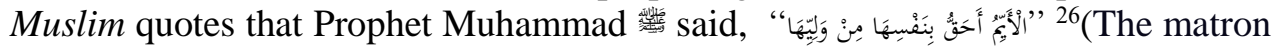
has more right to herself than her Walī,). This Hadithalso proves that a woman is entitled to marry herself.

Although the guardians are authorized of annulment of the marriage, but they cannot do so on their own but will present the case before the Qazi (Judge). Separation will only be made if the $Q \bar{a} z \bar{l}$ (Judge) wants the separation between two spouses but the parties do not have the power to forcibly break their marriage. $^{27}$

The guardians own such type of right if the couple is issueless. Otherwise such right of them will expire as it will affect the life of child. ${ }^{28}$

\section{Other Aspects:}

If a man or a woman gets married in such a way without the consent of their elders, though they fulfill other Sharia's formalities, they are considered a runaway couple. In Pakhtūn society men folk are given some relaxation in such matters but female are treated harshly and are liable to be given death penalty if commit such acts. So such couples are on the run and are killed wherever and whenever they are found by their respective families

Usually in such murders, the support of those $A H$ hàīūâdith is taken in which something has been said about such incidents. The incident of Sa'ad Bin Ibādah (May Allah be pleased with him) is narrated in the book of Sahīh Bukhārī under the title of Bāb-ul-Ghairat. When the verses of the Holy Qur'an' الذين يرمون المحصنات' "reveal where the commandments about $L e^{\prime}$ an were revealed to which Sa'ad Bin 
Ibādah (May Allah be pleased with him) said, O messenger of Allah! "When I see my wife with another man then shouldn't I say anything to them until I bring four witnesses to you?" Prophet Muhammad said, "No doubt, you will do the same" .Sa'ad Bin Ibādah (May Allah be pleased with him) said, "No, O messenger of Allah! I will kill the person at that very moment with the sword". Prophet Muhammad said to Sahābah, "Are you listening to your leader? What is he saying? The Sahābah said, "O Prophet! Do not rebuke him as he is an angry man. ${ }^{29}$

In the aforementioned incident it is crystal clear that Prophet Muhammad did not accept the opinion of Sa'ad Bin Ibādah (May Allah be pleased with him). When the Sahābah requested him not to rebuke him clearly shows that there appeared marks of dislike on the face of the Holy Prophet It proves that nobody is allowed to kill his wife on such situations. He may threaten them with the prospect of divorce rather than killing her. He should live with her if he can't leave her due to some compulsion i.e. in today's era, due to the fear of paying a lot of dowry, it's hard enough for a husband to leave his wife. A Hadithsubstantiates it well:

It is narrated by Ibn Abbas (May Allah be pleased with him) that a person complained about his wife to Prophet Muhammad that she didn't stop herself to have sex with other people. Prophet Muhammad advised him to leave her. He said, "O Prophet of Allah! I am afraid then I will be after her". Hearing that Muhammad directed him to keep and get benefited from her. ${ }^{30}$

Another such case was brought in the court of Prophet Muhammad. A Sahāa $\bar{\imath}$ named Aumeer Ajlān̄̄ (May Allah be pleased with him) said, "O Prophet of Allah! Tell me about that person who finds his wife with a stranger and he is sure about that person to have had sex with his wife, then should he kill that person? Prophet Muhammad said to Aumeer Ajlānī (May Allah be pleased with him) to call his wife as Allah revealed certain rules in such cases. By calling both in the mosque, he made $l e^{\prime} \bar{a} n$ between them. (A process of swearing between husband and wife in case of any charge $)^{31}$

$L e^{\prime} \bar{a} n$ and Mulāna'ah mean to curse one another. In religious terms Le'ān is certain type of swears or oaths between husband and wife. For instance if a husband imposes the charge of zinā (adultery) on the wife, then our religion bounds him to bring four witnesses to defend his case. The charged woman will be punished in case her husband succeeds in bringing four witnesses. Otherwise the process of swearing $\left(L e^{\prime} \bar{a} n\right)$ will be done between them. It is indeed hard enough to search for witnesses in case one's wife is seen so but following Shari'ah is more important than the so-called honour.

\section{Sharia's Rulings about Individual's Power Utilization against Perpetrator:}

Some of the regulations should be taken into account in this regard:

I. Does Shari'ah allow one to use his own power instead of court?

II. What should be the limit of power utilization?

III. What is the sharia directive if both or one of them is killed? 
First of all, it is pertinent to know whether the power utilization is justified and

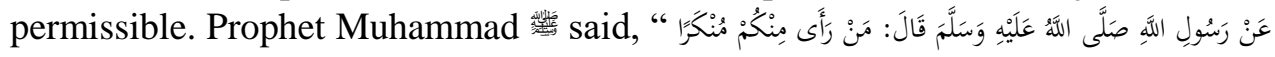

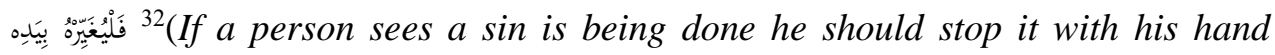
first). It looks clear from this Hadiththat the punishment is justified against the offenders.

Similarly according to the famous book of Hanafi jurisprudence, Tanvīr-ul-Absār;

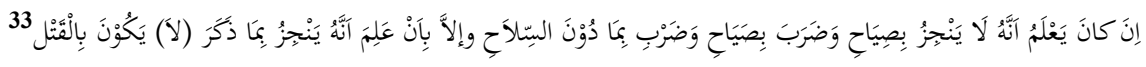

It means that the criminal should be killed if he is not likely to come to the track by pressurizing or punishment. Otherwise killing of the offender is not permissible in Islamic Shari'ah. The said saying allows punishing of the of offender under the rule of stopping vices (هي عن المنكر) but again it cannot be made a ground to afflict punishment because it says that the criminals may only be punished if they are found committing the heinous act. They are not ready to abstain from the act even after corporal punishment or a chance to flee from the place.

These days the situation is reverse. A man or a woman if accused of being guilty, the couple is murdered brutally after due consultation of the elders or the influential of the society. In some cases, both the parties assign the responsibility of murder to some other person. The killer should be executed if he couldn't bring four witnesses to clarify the attempted murder.

Keeping in view the narrations of $A b \bar{u}$ Dāūd and Aumeer it is crystal clear that punishing them is not permissible, rather the case should be presented to the judge or ruler of day. As Allāma Shāmī has written; "If the owner of the house doesn't have any witness to prove that the thief is indulged in such type of evil acts, he (owner of the house) is due to be killed in compensation. The owner of the house should even be killed if the thief is notorious in such tasks ${ }^{34}$."

\section{Nature of Honour Killing:}

Allah Almighty says in Quran in Surah al-Maida verse 32 and 33 that killing of an innocent person is like killing the whole community. And the person may be considered to be in war against Allah and his Prophet as one who spreads unrest on earth. Such a person should either be killed or hanged, exiled or his hands and feet may be amputated. This verse was revealed about those people of tribe Ukal and Uraina who were not actually Muslims but showed themselves Muslims and later converted and robbed camels from treasury after killing a person. ${ }^{35}$ The jurists and commentators are of the view regarding the revelation of these verses that these commandments are about those people who try to rob people by sitting in the form of groups terrorizing people. The people dare not go on the way where robbers are seated. So those people have made their path risky and the people have fear in their hearts. The same situation arises if a person is accused of murder and murder plans are made against him. Thus, a person may lead a life in terror as fear of death looms large on him. 
On the other hand, the person having the intentions of killing the offender has neither fear nor any threat from his society. In such situations both the murder and murderer are appreciated by the members of the society. After the murder, the affected families feel relaxed from the burden of honour and it is considered a matter of pride for them. In this case, under an unspoken agreement, both the parities forgive one another. The ratio of such crimes rises owing to leaving such killers free. In such cases, the state reserves the right to take action against perpetrators. Despite the forgiveness of the victims, the state is authorized to issue the penal law so that the crime can be dismantled in the society. In Quranic verse, the wisdom behind the revenge in the verse is that protection of the society is only possible through compensational revenge. While it is mentioned also in Surah Al-Maida, "To kill a person is like killing the whole humanity." Therefore the state reserves the right to take action against such perpetrators. Sometimes the victim's family wants the perpetrators to be punished but due to the influential families of the killers and comparatively their own weak position, they withdraw from their stance of taking revenge. Sometimes the issue is resolved through Diyyat (mutual bargain of the parties involving money) if the killers are willing and wealthy enough to pay the compensation money. The ruler has the authority to investigate and to ensure that the victim accepted Diyyat willingly or due to pressure. As is clear from the narration of Prophet's companion, Ali (May Allah be pleased with him) that once a Muslim was brought before him who had murdered a dhimmi, he gave the decision of killing the Muslim but later on the brother of the deceased forgave him. Ali asked if they had done it under pressure. The brother of the deceased responded that in any case, his brother couldn't get back, so he forgave them by taking Diyyat. Ali (May Allah be pleased with him) acceded to his wish. ${ }^{36}$

Similarly the Government has the authority to kill the perpetrator, even without consulting the guardians, if they think the offence more serious. As for instance, in Sunan-ul-Kubrāa, a book of Ahāīth, an incident has been reported that Hāris bin Suwayd (May Allah be pleased with him) took the revenge of his father by killing Mujzar Bin Ziad (May Allah be pleased with him) under a misconception in the battle of Uhad. Prophet Muhammad later ordered the assassination of Hāris Bin Suwayd (May Allah be pleased with him) when he came to know that revenge was taken by him although heirs of Mujzar Bin Ziad (May Allah be pleased with him) were present at that time. The Prophet did not ask them to offer any Diyyat. $^{37}$

It clearly indicates that, despite of the forgiveness of the victim's family, the government can take notice and issue his death warrant in compensation without asking the heirs of the victim if it deems his killing appropriate.

Extent of Public Power and Exercising Level besides Government:

As the state is authorized to issue the jurisdiction, similarly the criminal penalty is also at the disposal of state. As is in the famous jurisprudence book of Tanwīr ul Absārr; ${ }^{38}$ 
The meaning of discretionary punishment is that it is not fixed by Sharia but depends on the $Q \bar{a} z \bar{\imath}$ 's discretion.

Qāzī or Imām does have the authority to kill or imprison the offender. In case of serious offence he can issue orders of his murder. But this death penalty is not the divine punishment rather would be discretionary punishment and even Imam can forgive if he considers it appropriate. Regarding that it is narrated by Prophet that Abu Abdullah (May Allah be pleased with him), a renowned scholars among Sahā $\bar{a} \bar{a}$, says that Zakāt, divine punishment and Friday prayer is the responsibility of a ruler or imām. ${ }^{39}$

Some of the specifications of Hanfi jurists are present in this regard that who say that Imam is authorized to issue the divine punishment to maintain collective interests and discipline. As Abū Bakkar al-Jassās (May Allah be pleased with him) reported in Ahkam-ul-Qur'än: the scholars know the matters related to punishment as to when to cut off the hands of a man or a woman on robbery or to whip in case of adultery. ${ }^{40}$

\section{Conclusion:}

The concept of a governing body or government will vanish if and when everyone seeks to avenge the culprit on his own. Personal action in such matters may lead to more personal rivalries. Besides, there are high chances of injustice being done regarding the punishment because small offense can be treated with tough punishment. The culprit, being powerful, can again take revenge from the person which will be an additional offense. Allāma Kāsān̄̄ said, "Imām is authorized to set the punishment on the common public due to the supremacy of power and force and there are zero chances of rivalry with Imam. Neither can there be any suspicion of partiality, favour and flattery on them ". ${ }^{41}$

Under the judiciary and constitutional frame, reliable witnesses are needed before awarding punishment to a culprit. The witnesses are checked for the authenticity of their evidence and it is ensured that the witnesses are not lying and that all the prerequisites are fulfilled by an empowered court which is under the influence of an Imam. Therefore according to the rule of Islamic Shari'ah, the state has the authority to punish a criminal. Now a person, taking action against the offender himself will also be considered as criminal of the state because this person interfered in state affairs and the work entrusted to another person was done by him without taking permission. In legal term the word "Aftiyat" is used as is in "Mawsughat-ul-Fiqhiah".

Aftiyat ${ }^{42}$ in the current parlance denotes as to take the law in hands. Aftiyat is not considered legal as it is interference in the entrusted work of others and rights of other person is definitely influenced. ${ }^{43}$ It is for the state or the persons/offices appointed by the state to pronounce someone guilty or not. Similarly under the chapter of divine punishment, a person issuing a penalty against someone on his personal opinion will be punished due to misuse of Imam's rights. According to "al-Mawsüghat-ul-Fiqhiah" Aftiyat is not valid because it is considered interruption in others' rights. Sometimes intervention is made in the work of rulers while sometimes in the work of layman. If one performs the function of a 
ruler by himself, it is considered an undue interference and criminal punishment is a must for such a person. ${ }^{44}$

Jurists agree on this that establishment of Hudood (divine punishments) is the responsibility of the rulers or deputy-rulers whether this $\mathrm{Had}$ (divine punishment) is necessary due to Allah's rights i.e. adultery charges are a must due to a man's rights. Ijtihād is needed to set the limits and there remains a fear of injustice so it is essential that this right should be entrusted to ruler. Prophet also set the limits in his life. Similarly all the caliphs established divine punishment. Now if someone establishes divine punishment without a ruler's permission then jurists agree there would not be compensation upon the murder as the apostate deserved to be murdered. The murder of the apostate was forgiven. But penalty will be a must for that person due to interference in the work of the rulers.

So no citizen is allowed to take the law in his hands by punishing others by himself. If one does such work then this person will be guilty and legal suitable punishment can be suggested for him ${ }^{45}$.

Recommendations of the study:

The aforementioned discussion can be summed up in the following words:

- Islamic Shari'ah has permitted women to enjoy freedom of education, legitimate entertainment, trade, custom and marrying with men of their own choice within certain boundaries and restrictions of Shari'ah and the guardians have been warned to stop them in doing so.

- Nobody is allowed to execute a woman in the name of so-called honor.

- If a person kills a woman in society, it clearly means he is doing so to make people afraid of him and it falls in the category of Fasād fil Ard.

- The government is fully authorized to deal the case itself even if the saints of victim have forgiven the blood of the victim and try to look into the matter and take appropriate action. The government can also take compensation from the offender.

- No one is authorized to take law in hand. Only the ruler or judge should decide whether to forgive or punish a person.

- The ruler should give exemplary punishment to the person who commits the so-called honour killing to ensure a peaceful and tranquil society.

\section{(c) This work is licensed under a Creative Commons Attribution 4.0 International Licence.}

\section{References:}

1 Mosquera, P. M. R., Manstead, A. S., \& Fischer, A. H. (2002). The role of honour concerns in emotional reactions to offences. Cognition \& Emotion, 16(1), 143-163.

2 Abu-Odeh, L. (2011). Crimes of honor and the construction of gender in Arab societies. Comparative Law Review, 2(1). 
3 Patel, S., \& Gadit, A. M. (2008). Karo-Kari: A Form of Honour Killing in Pakistan. Transcultural Psychiatry, 45(4), 683-694.

4 Al-Asqalānī, Hāâiz Ibn Hajar, Fath̆ ul Bārī, Dār ul ma'rifah, Bayrūt, Vol: 8 page: 324

5 Fawzī, A. (2018). Kontekstualisasi Makna Hadis Siwak Melalui Pendekatan Hermeneutika Fazlur Rahman. Journal of Hadīth Studies, 1(2). \& Fath ul Bārī Vol: 8 page : 326

6 Al-Isāba fi Tamyīz e Saḥāba Vol: 8 page: 241

7 Green, M. C., \& Sabini, J. (2006). Gender, socioeconomic status, age, and jealousy: Emotional responses to infidelity in a national sample. Emotion, 6(2), 330.

8 Eisner, M., \& Ghuneim, L. (2013). Honor killing attitudes amongst adolescents in Amman, Jordan. Aggressive Behavior, 39(5), 405-417.

9 Crook, Z. (2009). Honor, shame, and social status revisited. Journal of Biblical Literature , 128(3), 591-611.

10 Welchman L. Honour: Crimes, Paradigms and Violence against Women (Review). Hum Rights Q [Internet]. 2007;29:524-33. Available from: http://eprints. soas.ac.uk/2826/

11 Niaz U. Violence against women in South Asian countries. Arch Womens Ment Health [Internet]. 2003 Aug 1 [cited 2015 Oct 7];6(3):173-84. Available from: http://link.springer.com/10.1007/s00737-003-0171-9

12 Douki S, Nacef F, Belhadj a, Bouasker a, Ghachem R. Violence against women in Arab and Islamic countries. Arch Womens Ment Health [Internet]. 2003 Aug [cited 2015 Oct 14];6(3):165-71. Available from: http://www. ncbi.nlm.nih.gov/ pubmed/12920614

13 Lari MZ. Honor Killing in Pakistan and Compliance of Law by. A Pilot Case Study 'Honor Kill Pakistan compliance law. 2011.

14 Korteweg AC, Yurdakul G. Religion, Culture and the Politicization of Honour-Related Violence. 2010;(12).

15 Ibn Abdul Bar, Yousaf bin Abdullah Al Qurtabī, "Al-Ista,ab Fi Ma,arifat il Asḥāb, Dār ul Jayl, Bayrūt, Vol:4 page: 186

16 Tah̆zīb ul Asmā wal Lughat, Abū Zakria, Muhyiddin, Yahya bin Sharf al Nawawī,Dār Ul Kutub Al-Ilmiah, Bayrūt, Vol:2, page:97

17 Al-Isti'äb Vol:4 page: 1787

18 Al-Isābah Vol: 8 page: 240

19 Tah̆zīb ul Asmā: page:346

20 Al-Isti'āb Vol:4 page 1868

21 Ibid: Vol:4 page: 1863

22 Al-Isābah $\mathrm{Vol}: 8$ page: 165

23 Sulaymān bin Al ash,as, Abū Dāwūd, Sunan Abi Dāwūd, Dār ul Fikar,Vol:1 page: 635, Hadith No: 2085

24 Muhammad bin Isā Abū Isā al-Tarmizì, Sunan Tarmizì, Vol:3 page:407, Hadīth No:1102 
25 Meḥmod bin Umer, Al Zamkhsharī, Jārullah, Al Kashāf, Dār al Kitāb, Al-Arabī Bayrūt Vol: 1, Page: 277

26 Muslim bin Al-Hajjāj, Saḥịh Muslim, Dār ul Ihyyā ul Turāth, Al-Arabī, Bayrūt, Vol:2 page: 1037, Hadith No: 1421

27 Abdul Rehman bin Muhammad, Majm'a ul Anhar fi Multaqa Al-Abhar, Dār ul Ihyā ul Turāth, Al-Arabī, Vol:1, Page:332

28 Ibid

29 Fath ul Bārī: Vol:9 page: 321

30 Abu Dāwüd Vol:2 page: 175 Hadìth No: 2051

31 Muhammad bin Ismail al-Bukharī, Saḥịh al-Bukharī, Hadīth No: 5308, Dār ul Touq Nijāt

32 Muhammad bin Abdullah, Mishkāt Al-Masābīh, Al-maktab ul Islāmī, Bayrūt, Vol:1, page 119

33 Al-Durul Mukhtār, Al-Haskafī, Dār ul Fikar Bayrūt, Vol: 4, page: 63

34 Rad ul Mukhtār, Ibn-e-Aabidīn, Vol:4, page: 64

35 Abu Al-Fida Ismail bin Umer bin Kathir, Tafsìr al Qur'ān al-Azìm, Vol:3 page: 95

36 Ahmad bin Al Husain, Al Sunan Al kubrā, encyclopedia, Vol:8 page: 34 Hadìth No: 16356

37 Ibid Vol:8 page:57 Hadith No: 16485

38 Al Dur al Mukhtār Vol: 4 page: 62

39 Fatḥ ul Bārī, Vol: 3 page: 163

40 Ahkā̄m ul Qur'ān, al Jassās, Dār ul Ihyā al Turāth, Al-Arabī, Bayrūt vol: 5 page:131

41 Alāudin Abu Bakkar bin Masood al kāsān̄̄, Bidāya al Sanāya Dār ul Kutub al-Ilmiya Vol:7, page 57

42 Al-Mawsü'a al-Fiqhiya Vol:5 page: 280

43 Ibid

44 Ibid

45 Ibid 